\title{
Induction of early rutting in male red deer (Cervus elaphus) by melatonin and its dependence on LHRH
}

\author{
G. A. Lincoln, H. M. Fraser and T. J. Fletcher* \\ M.R.C. Reproductive Biology Unit, Centre for Reproductive Biology, 37 Chalmers Street, Edinburgh \\ EH3 $9 E W$, and ${ }^{*}$ Reedie Hill Deer Farm, Auchtermuchty, Fife KY14 7HS, U.K.
}

\begin{abstract}
Summary. Eight red deer stags, 2 control, 3 control-immunized (i.e. a low titre of LHRH antibodies after active immunization 2 years earlier) and 3 superior cervical ganglionectomized, were given a s.c. implant of melatonin in May at the nadir of the sexual cycle; 5 other stags remained untreated. All the melatonin-treated animals shed the velvet-like skin from the antlers in June or July at least 1 month before the untreated controls, and had an early increase in blood plasma testosterone concentrations. The treated stags were also precocious in the development of rutting behaviour, although this inductive effect was blocked dramatically in the controlimmunized stags after a booster immunization against LHRH; these animals failed to show any further reproductive development and cast their antlers.

It is concluded that continuous exposure to melatonin in early summer will induce premature seasonal testicular development, an effect dependent on the secretion of LHRH, and similar to that produced by exposure to short daylengths.
\end{abstract}

\section{Introduction}

The seasonal cycle of rutting behaviour and the growth and casting of the antlers in red deer (Cervus elaphus) is regulated by the seasonal cycle in the secretion of testosterone from the testes (Lincoln, Youngson \& Short, 1970; Lincoln, 1971; Lincoln, Guinness \& Short, 1972). This endocrine control results in stags being most sexually active and aggressive at the peak of the sexual cycle in October (the rut), with dead bony antlers which can function as weapons in inter-male rivalry. The seasonal change in daylength acts as the principal environmental cue which precisely times these seasonal events (Marshall, 1937; Jaczewski, 1954; Pollock, 1975), and recent evidence from related deer species indicates that the response to daylength is dependent on a functionally active pineal gland (Plotka, Seal, Letellier, Verme \& Ozaga, 1981; Bubenik, 1983; Lincoln, 1983, 1984). Detailed studies on sheep have shown that it is the daily pattern of melatonin secretion from the pineal that acts as the endocrine signal that relays the effects of photoperiod on reproduction and other seasonal characteristics (Rollag, O'Callaghan \& Niswender, 1978; Lincoln \& Almeida, 1981; Bittman, Dempsey \& Karsch, 1983). In the present study we have recorded the effect of a subcutaneous implant of melatonin on the seasonal reproductive cycle of stags, implanting the animals in early summer during long daylengths with the aim of inducing a short-day response, i.e. early rutting. Red deer are now farmed extensively, and implantation with melatonin may provide a simple method to manipulate the onset of the rut, thus controlling the calving season to a commercial advantage.

\section{Materials and Methods}

Animals. Observations were made on 13 sexually mature red deer stags aged 3-6 years, living out-ofdoors at the Reedie Hill Deer Farm in Fife $\left(56^{\circ} \mathrm{N}\right)$. The animals were free to graze in large paddocks with other stags, carried identification collars and were inspected every 1-3 days from May to November 1983 to record any changes in the antlers and behaviour. 
The experimental group consisted of (i) 7 normal stags (controls), (ii) 3 normal stags with a low titre of LHRH antibodies (control-immunized) because they had been actively immunized with an LHRH conjugate in 1981 (Lincoln, Fraser \& Fletcher, 1982) but had resumed normal seasonal cycles in antler growth after the decline in antibody titre, (iii) 3 stags (SCGX) that had had the superior cervical ganglia removed in 1978 by the method of Appleton \& Waites (1955) to denervate the pineal gland and other cranial structures but were still capable of exhibiting regular annual cycles in antler growth and rutting behaviour out-of-doors (Lincoln, 1984).

Experimental procedures. On 3 occasions (May, July and September) all the stags were immobilized using 1.5-2 $\mathrm{ml}$ etorphine hydrochloride, methotrimeprazine and acepromazine (Immobilon: Reckitt \& Coleman, Hull, U.K) injected by a projectile dart. After the minor experimental manipulations, including the collection of blood samples, the sedation was reversed by an antidote, diprenorphine (Revivon: Reckitt \& Coleman). On 18 May, 8 of the stags ( 2 control, 3 control-immunized, 3 SCGX) were given a s.c. implant of melatonin consisting of a sealed envelope of Silastic sheeting, surface area $42 \mathrm{~cm}^{2}$ (500-1 sheeting, Dow Corning, Midland, MI, U.S.A.), containing $1.0 \mathrm{~g}$ melatonin (Sigma, Poole, Dorset, U.K.), placed under the skin on the inside of the thigh. Such implants have previously been shown to maintain a blood level of 100-400 $\mathrm{pg}$ melatonin/ml continuously for many months when given to sheep (Lincoln \& Almeida, 1981; G. A. Lincoln \& F. J. P. Ebling, unpublished results). On 25 July, the 3 control-immunized stags were given a booster immunization with an LHRH-porcine thyroglobulin conjugate (Lincoln et al., 1982) and used to stimulate the production of LHRH antibodies to neutralize endogenous LHRH. During September, all the stags were given an i.v. injection of $25 \mu \mathrm{g}$ ovine LH (NIH-LH-S19) to test the responsiveness of the testes, and blood samples were collected from the jugular vein at 30-min intervals for $2 \mathrm{~h}$ while the animals remained sedated with etorphine. All blood samples were placed on ice, and the plasma was separated and frozen at $-20^{\circ} \mathrm{C}$ until required for the hormone and antibody titre measurements.

Assays. Testosterone concentrations in the blood plasma were determined by a specific radioimmunoassay (Corker \& Davidson, 1978) which had a limit of detection of $0.1 \mathrm{ng} / \mathrm{ml}$ and an intra-assay coefficient of variation of $8.5 \%$. The titres of LHRH antibodies were measured as described previously (Lincoln et al., 1982) and expressed as the dilution of plasma capable of binding $33 \%$ labelled LHRH.

\section{Results}

The effects on the reproductive cycle of implanting melatonin in early summer are summarized in Text-fig. 1. The treatment caused precocious sexual development in all 8 animals. The velvet-like skin was shed from the antlers of the melatonin-treated stags prematurely in June or July, at least 1 month before shedding by the untreated controls; the antlers of these stags were also stunted and displayed incomplete development of the distal tines (Text-fig. 1; Pl. 1, Figs 1-4). On 25/27 July, when the state of the antlers of the treated and untreated stags was markedly different, testosterone values were significantly higher $(P<0.01$, Student's $t$ test $)$ in the treated $(15.7 \pm 3.4 \mathrm{ng} / \mathrm{ml})$ than in the untreated $(1.8 \pm 0.7 \mathrm{ng} / \mathrm{ml})$ stags. At this time, the other male secondary sexual characteristics, including swelling of the neck musculature, growth of the neck mane and development of the rutting odour in the urine, were all more advanced in the melatonin-treated stags (Table 1 ; Pl. 1, Figs 1 \& 2). These animals were also growing their winter coat prematurely, and they began to show rutting behaviour (roaring, wallowing, pacing the perimeter fence near the hinds, courting young stags and showing overt aggression to other stags) in late July and early August, at least 6 weeks before the control stags, and at an earlier time than had ever been recorded previously on the deer farm.

The stimulatory influence of the melatonin treatment on the autumn sexuality was apparent in 


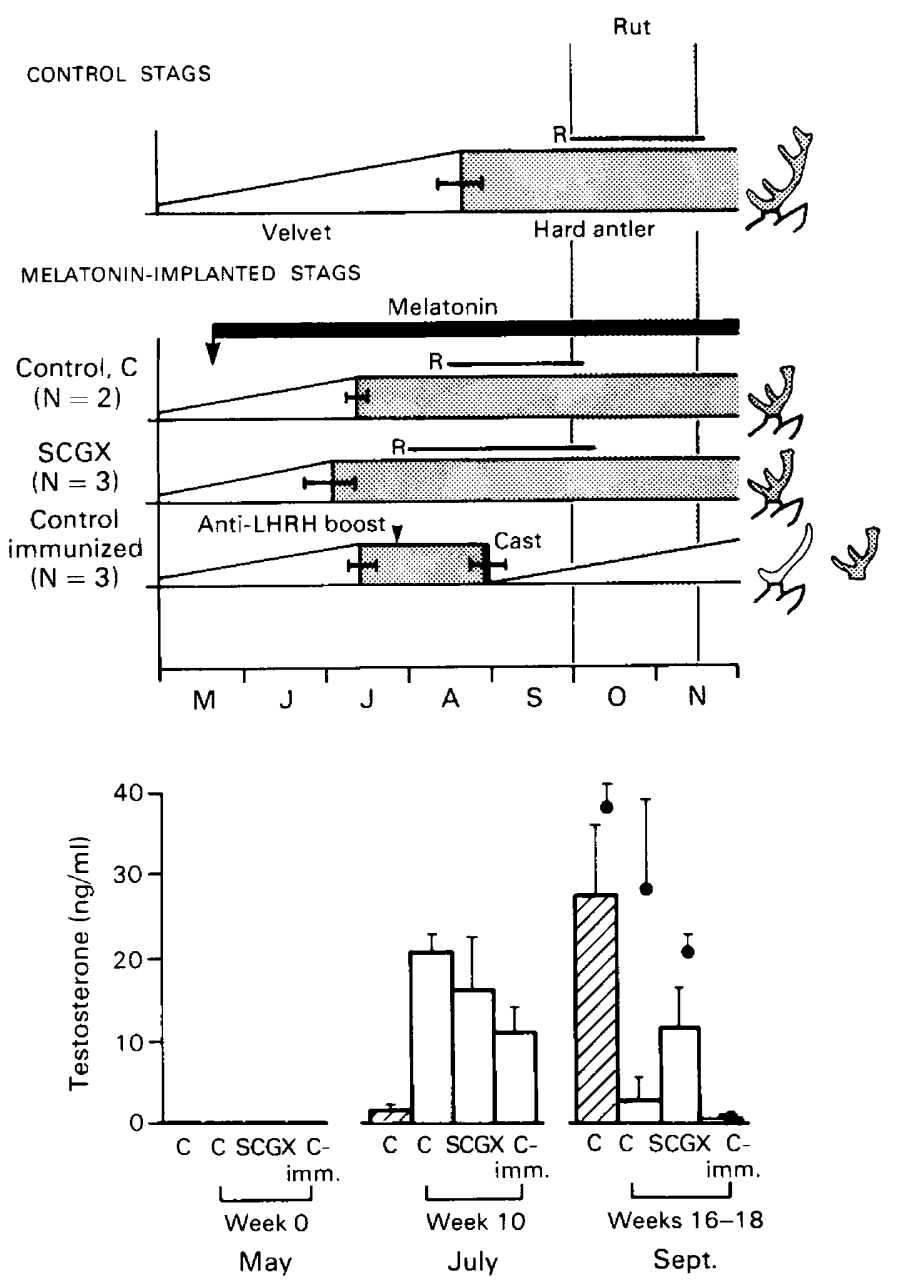

Text-fig. 1. Changes in the antler cycle (broad horizontal bar, indicating period of velvet and hard antler, mean and range), rutting behaviour (horizontal line preceded by $R$ ) and blood plasma concentrations of testosterone (histograms below), in 5 untreated controls (mean \pm s.e.m.) and 8 melatonin-implanted red deer stags (mean and range) studied from May to November 1983. The melatonin-treated stags consisted of 2 normal stags (Control, C), 3 superior cervical ganglionectomized stags (SCGX), and 3 normal stags carrying a low titre of LHRH antibodies (control-immunized, C-imm.). Basal testosterone values in May, July and September are represented as histograms while the maximum concentration of testosterone occurring after the i.v. injection of LH in September is represented as 0 . The shape of the antlers at the end of treatment is also illustrated.

all 3 groups of stags, with the SCGX stags being the most precocious. The control-immunized animals were given the booster immunization to induce LHRH antibodies on 25 July, at a time when testicular redevelopment was well underway and the antlers had shed the velvet-like skin 515 days earlier (Text-fig. 1). The booster immunization stimulated an increase in the LHRH antibody titre ( $1: 170,1: 1050$ and $1: 1550$ in July before booster, compared with $1: 1200,1: 6400$ and $1: 25000$ in September for the 3 animals respectively; see Text-fig. 1) and this was associated with a complete block on the seasonal reproductive development induced by the treatment with melatonin. The cleaned antlers were cast $29-41$ days after the immunization, indicative of a 
Table 1. Reproductive characteristics (mean with range in parentheses) of control and melatoninimplanted red deer stags on $25 / 27$ July 1983

\begin{tabular}{|c|c|c|c|c|}
\hline & \multirow[b]{2}{*}{$\begin{array}{l}\text { Untreated stags } \\
\text { (control, } \mathbf{N}=5 \text { ) }\end{array}$} & \multicolumn{3}{|c|}{ Melatonin-implanted stags } \\
\hline & & $\begin{array}{c}\text { Control } \\
(\mathrm{N}=2)\end{array}$ & $\begin{array}{l}\text { SCGX } \\
(\mathrm{N}=3)\end{array}$ & $\begin{array}{l}\text { Control-immunized } \\
\qquad(\mathrm{N}=3)\end{array}$ \\
\hline $\begin{array}{l}\text { Plasma testosterone } \\
(\mathrm{ng} / \mathrm{ml})\end{array}$ & $\begin{array}{c}1 \cdot 8 \\
(0 \cdot 2-3 \cdot 6)\end{array}$ & $\begin{array}{c}21 \cdot 7^{*} \\
(20 \cdot 2-23 \cdot 1)\end{array}$ & $\begin{array}{c}16 \cdot 1 \\
(2 \cdot 9-25 \cdot 5)\end{array}$ & $\begin{array}{l}12 \cdot 1^{*} \\
(9 \cdot 4-17 \cdot 1)\end{array}$ \\
\hline $\begin{array}{l}\text { Testis diam. } \\
\quad(\mathrm{mm})\end{array}$ & $\begin{array}{c}42 \\
(37-45)\end{array}$ & $\begin{array}{c}46 \\
(45-47)\end{array}$ & $\begin{array}{c}46 \\
(45-49)\end{array}$ & $\begin{array}{c}38 \\
(37-40)\end{array}$ \\
\hline $\begin{array}{l}\text { Neck girth } \\
(\mathrm{cm})\end{array}$ & $\begin{array}{c}56 \\
(47-61)\end{array}$ & $\begin{array}{c}60 \\
(58-62)\end{array}$ & $\begin{array}{c}74^{*} \\
(72-76)\end{array}$ & $\begin{array}{c}60 \\
(60-61)\end{array}$ \\
\hline $\begin{array}{l}\text { Neck mane } \\
(\mathrm{cm})\end{array}$ & $\begin{array}{c}5 \cdot 8 \\
(5 \cdot 0-7 \cdot 0)\end{array}$ & $\begin{array}{c}7 \cdot 5 \\
(7 \cdot 0-8 \cdot 0)\end{array}$ & $\begin{array}{c}8 \cdot 0^{*} \\
(7 \cdot 5-8 \cdot 5)\end{array}$ & $\begin{array}{c}6 \cdot 0 \\
(4 \cdot 5-6 \cdot 5)\end{array}$ \\
\hline $\begin{array}{l}\text { Body coat } \\
\text { (summer/winter) }\end{array}$ & Summer/Winter & Winter* & Winter* & $\begin{array}{l}\text { Winter* (hind-like } \\
\text { in one case) }\end{array}$ \\
\hline $\begin{array}{l}\text { Antler length } \\
(\mathrm{cm})\end{array}$ & $\begin{array}{c}68 \\
(48-91)\end{array}$ & $\begin{array}{c}33^{*} \\
(25-40)\end{array}$ & $\begin{array}{c}70 \\
(50-81)\end{array}$ & $\begin{array}{c}32^{*} \\
(25-40)\end{array}$ \\
\hline $\begin{array}{l}\text { Antler state } \\
\text { (velvet/hard antler) }\end{array}$ & Velvet & Hard antler* & Hard antler* & Hard antler* \\
\hline Rutting odour/stain & None & Slight* & Slight ${ }^{*}$ & None \\
\hline Rutting behaviour & None & Slight* & Well advanced ${ }^{*}$ & Very slight* \\
\hline
\end{tabular}

* No overlap with untreated controls.

castration response, and the stags developed a new set of antlers and showed no further development of the rutting characteristics (P1. 1, Fig. 4). Plasma concentrations of testosterone became very low in these animals and failed to respond to an i.v. injection of $25 \mu \mathrm{g}$ ovine LH (Textfig. 1).

By late September, the blood levels of testosterone had declined in the melatonin-treated control and SCGX stags compared to the values in July, although high levels were obtained after injection of LH (Text-fig. 1). By this stage, the testosterone concentrations in the untreated controls were very high, and these animals had begun to develop rutting behaviour at the expected time. The rutting phase for the melatonin-treated animals (excluding the immunized group) ended in early October, at least 6 weeks earlier than normal, by which time they appeared to have lost weight typical of a stag following the rut. In contrast, the control-immunized stags which had not rutted in response to the melatonin were in good body condition.

\section{Discussion}

These results illustrate that melatonin given as a subcutaneous implant in early summer, at the nadir of the sexual cycle, will stimulate the early onset of the mating season. The inductive effect occurred in ganglionectomized stags indicating that it does not depend on a functional pineal gland. In the treated stags, the hypothalamic-pituitary-testis axis appeared to be switched 'on' prematurely, and the resulting increase in testosterone secretion dictated the changes in the antlers, male body characteristics and behaviour. The drive to the reproductive system was dependent on LHRH secretion (presumably from the hypothalamus) since the inductive effects of melatonin were totally blocked by active immunization against LHRH.

Oral treatment of male white-tailed deer with melatonin, given daily in the afternoon during the early summer, induced early testicular development and rutting behaviour (Bubenik, 1983). Similar treatment in female sheep also led to the early onset of the breeding season (Kennaway, Gilmore \& Seamark, 1982a; Nett \& Niswender, 1982; Arendt, Symons, Laud \& Pryde, 1983). These daily 


\section{PLATE 1}
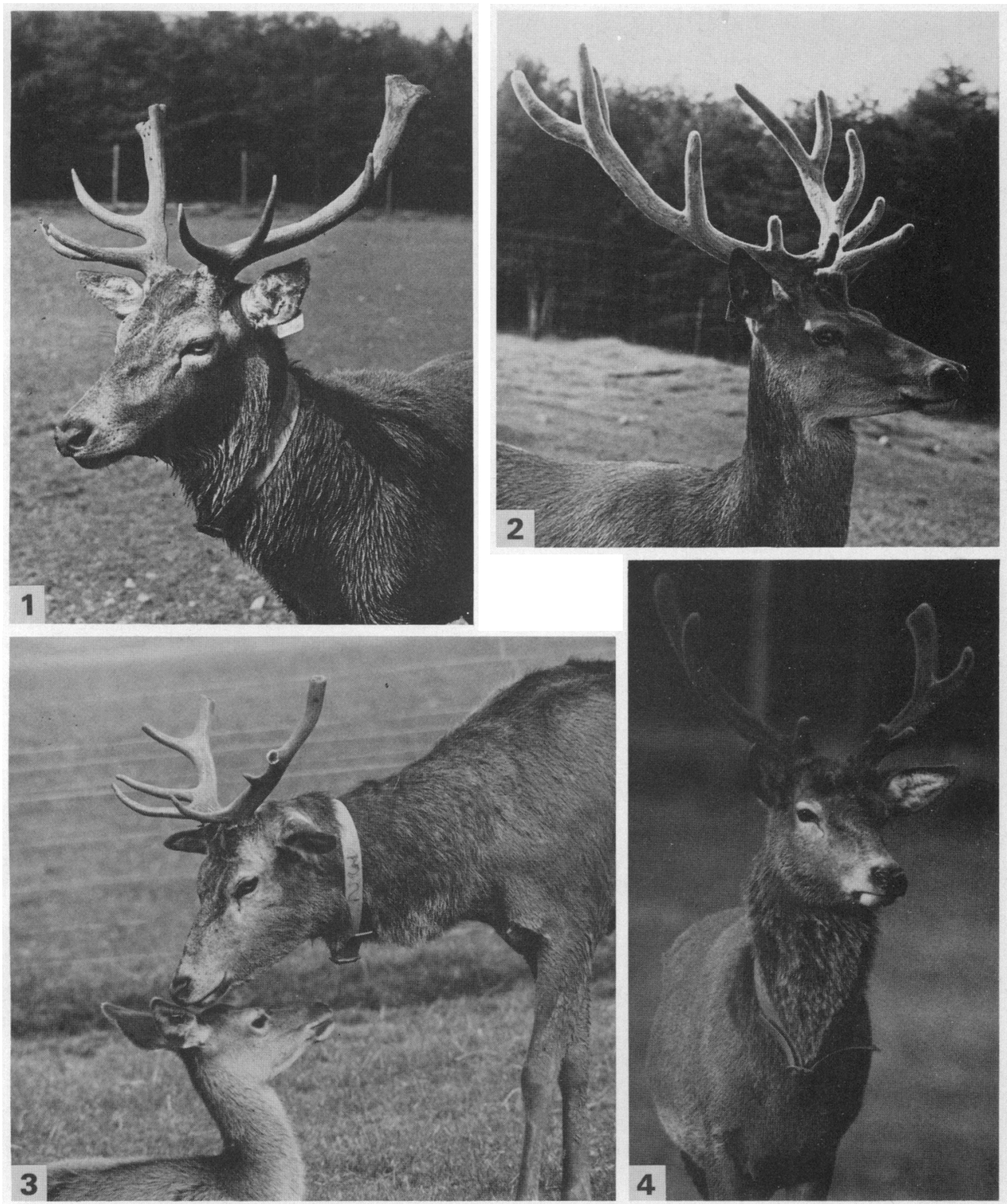

Fig. 1. Melatonin-implanted SCGX stag on 25 July 1983 showing the hard antlers with stunted top tines, a swollen neck and long neck mane indicative of precocious sexual development.

Fig. 2. Untreated control stag on 25 July 1983, still with the antlers covered by velvet-like skin, and the neck is thin and the neck mane undeveloped.

Fig. 3. Melatonin-implanted control stag on 25 July 1983 showing courtship behaviour towards a young hind at least 6 weeks earlier than normal. Note, the stag has hard antlers with stunted top tines due to premature shedding of the velvet-like skin.

Fig. 4. Melatonin-implanted control-immunized stag on 20 November 1983. This animal has just regenerated a new set of antlers following casting of the hard antlers in August due to a booster immunization against LHRH.

(Fucing p. 342) 
treatments are intended to produce a prolonged exposure to melatonin, as occurs during short days in the autumn and winter, and to trigger the short-day effects on reproduction. The present study shows that this short-day response can be induced simply by giving a subcutaneous implant of melatonin, thus avoiding the daily handling of the animals. Kennaway et al. (1982b) and Kennaway, Dunstan \& Gilmore (1983) have shown that a melatonin implant given to ewes during anoestrus will suppress prolactin secrection similar to that induced by exposure to short-days, but failed to observe an effect on the onset of the breeding season. Although induction of testicular activity occurred when the stags were treated with melatonin in May under long days, the animals showed a premature end to the breeding season, an apparent refractoriness to the stimulatory effects of constant melatonin.

In conclusion, it is evident that a melatonin implant is an effective way to induce early breeding in red deer and other short-day species and this could be used as a convenient method to manipulate the breeding season on the farm.

We thank Dr J. Sandow for the gift of LHRH, and NIAMDD for the supply of ovine LH.

\section{References}

Appleton, A.B. \& Waites, G.M.H. (1955) A surgical approach to the superior cervical ganglion and related structures in sheep. J. Physiol., Lond. 135, 5257.

Arendt, J., Symons, A.M., Laud, C.A. \& Pryde, S.J. (1983) Melatonin can induce early onset of the breeding season in ewes. $J$. Endocr. 97, 395-400.

Bittman, E.L., Dempsey, R.J. \& Karsch, F.J. (1983) Pineal melatonin secretion drives the reproductive response to daylength in the ewe. Endocrinology 113, 2276-2283.

Bubenik, G. (1983) Shift of seasonal cycle in white-tailed deer by oral administration of melatonin. J. exp. Zool. 225, 155-156.

Corker, C.S. \& Davidson, D. (1978) The radioimmunoassay of testosterone in various biological fluids without chromatography. J. Steroid Biochem. 9, 373374.

Jaczewski, Z. (1954) The effect of changes in length of daylight on the growth of antlers in deer (Cervus elaphus L.). Folia biol., Praha 2, 133-143.

Kennaway, D.J., Gilmore, T.A. \& Seamark, R.F. (1982a) Effect of melatonin feeding on serum prolactin and gonadotrophin levels and the onset of seasonal estrous cyclicity in sheep. Endocrinology 110, 17661772.

Kennaway, D.J., Gilmore, T.A. \& Seamark, R.F. (1982b) Effect of melatonin implants on the circadian rhythm of plasma melatonin and prolactin in sheep. Endocrinology 110, 2186-2188.

Kennaway, D.J., Dunstan, E.A., Gilmore, T.A. \& Seamark, R.F. (1983) Effect of shortened daylength and melatonin treatment of plasma prolactin and melatonin levels in pinealectomised and sham-operated ewes. Anim. Reprod. Sci. 5, 287-294.

Lincoln, G.A. (1971) The seasonal reproductive changes in the red deer stag (Cervus elaphus). J. Zool., Lond. 163, 105-123.

Lincoln, G.A. (1983) Melatonin as a seasonal time-cue: a commercial story. Nature, Lond. 302, 755.

Lincoln, G.A. (1984) Seasonal breeding in deer. In Biology of Deer Production. Eds K. Drew \& P.
Fennessey. Royal Society of New Zealand Joint Publication with Invermay Agricultural Research Institute, Dunedin. (In press).

Lincoln, G.A. \& Almeida, O.F.X. (1981) Melatonin and the seasonal photoperiodic response in sheep. In Photoperiodism and Reproduction, pp. 231-251. Eds R. Ortavant, J. Pelletier \& J.-P. Ravault. INRA, France.

Lincoln, G.A., Youngson, R.W. \& Short, R.V. (1970) The social and sexual behaviour of the red deer stag. $J$. Reprod. Fert., Suppl. 11, 71-103.

Lincoln, G.A., Guinness, F. \& Short, R.V. (1972) The way in which testosterone controls the social and sexual behaviour of the red deer stag (Cervus elaphus). Horm. \& Behav. 3, 375-396.

Lincoln, G.A., Fraser, H.M. \& Fletcher, T.J. (1982) Antler growth in male red deer (Cervus elaphus) after active immunization against LH-RH. J. Reprod. Fert. 66, 703-708.

Marshall, F.H.A. (1937) On the change over in the oestrous cycle in animals after transference across the equator, with further observations on the incidence of the breeding seasons and the factors controlling sexual periodicity. Proc. $R$. Soc. B 122, 413-428.

Nett, T.M. \& Niswender, G.D. (1982) Influence of exogenous melatonin on seasonality of reproduction in sheep. Theriogenology 17, 645-653.

Plotka, E.D., Seal, U.S., Letellier, M.A., Verme, L.J. \& Ozaga, J.J. (1981) Effect of pinealectomy on seasonal phenotypic changes in white-tailed deer (Odocoileus virginianus borealis). In Pineal Function, pp. 45-56. Eds C. D. Matthews \& R. F. Seamark. Elsevier/ North Holland, Amsterdam.

Pollock, A.M. (1975) Seasonal changes in appetite and sexual condition in red deer stags maintained on a six month photoperiod. J. Physiol., Lond. 244, 95P-96P, Abstr.

Rollag, M.D., O'Callaghan, P.L. \& Niswender, G.D. (1978) Serum melatonin during different stages of the annual reproductive cycle in ewes. Biol. Reprod. 18, 279-285.

Received 16 January 1984 